\title{
ASPECTS OF PENTECOSTAL THEOLOGY: RECENT DEVELOPMENTS IN AFRICA
}

Marius Nel

Lit Verlag. 2016. pp. 228

ISBN 978-3-643-90706-6

\section{Reviewed by Lovemore Togarasei}

University of Botswana

and Visiting Professor: Research Institute for Theology and Religion

University of South Africa, Pretoria

Itogarasei@yahoo.com

Although Africa has become the epicentre of Christianity, there are not many books produced in Africa explaining this phenomenon. This is particularly so with reference to Pentecostal Christianity. Pentecostal churches are fast becoming the major expression of Christianity in Africa, particularly in the sub-Saharan region. This development needs to be captured and documented not only for contemporary knowledge, but also for posterity. Thus the publication of the book, Aspects of Pentecostal theology: Recent developments in Africa by Marius Nel, is a welcome development. Although Allan Anderson (2004) and Obgu Kalu (2008) (among others) have published on African Pentecostalism, their works did not focus exclusively on Pentecostal theology, as Nel has done.

The book comprises 14 chapters, all focusing on Pentecostal theology of the Apostolic Faith Mission (AFM) in South Africa. Although he has not organised the chapters into related sections, one notices that the subjects treated in the chapters can be grouped into the following themes: Pentecostal spirituality identity; Pentecostal history; Pentecostal history and theology of healing; and Pentecostal hermeneutics. My review of the book will follow this structure.

Chapters 1, 3 and 4 (note that the book does not number the chapters so the reader has to count) address Pentecostal spirituality identity. In the first chapter, the author attempts to determine Pentecostal identity by defining the constitutive elements

\section{UNISA}


of a Pentecostal spirituality. The elements identified and discussed are the Bible, revivalism, restorationism and primitivism, the missional focus, and the centrality of the Spirit. Chapter 3 picks up the Pentecostal identity issue by looking at how Pentecostals differ theologically and practically from other Christian traditions like the Catholic or Reformed traditions. Nel's argument here is that it is the Pentecostal hermeneutic that defines Pentecostal theology and how it differs from other Christian traditions. Five distinctive features are then identified: conversion, sanctification, baptism of the Spirit, divine/faith healing and imminent eschatology. In the fourth chapter, Pentecostal spirituality identity is discussed in light of Pentecostals' attitude to the world. The author groups Pentecostal Christianity with other early primitivistic movements like the Montanists, Radical reformers, Pietists, etc. He then compares Pentecostalism and the early church on the subject of living distinctively from the world. This is a very detailed and interesting chapter that provides good background on the early church and proves the author's training in the New Testament. With this background given, the author concludes that Pentecostals are not quite living the distinct lifestyle of the early Christians.

Four chapters $(5,7,11$ and 12) address what I consider to be Pentecostal (AFM) history. Chapter 5 discusses the tradition of anti-intellectualism in the first five to six decades of South African Pentecostalism. The chapter outlines the tradition of anti-intellectualism, first noting that the appointment of church officers was based on perceived spiritual gifts rather than training. The most interesting section discusses reasons for this anti-intellectualism. Some of the reasons given are the origins of the movement among the poor and the uneducated, belief in imminent eschatology that saw training as a waste of time, and the belief that intellectualism would suppress the manifestation of the Holy Spirit. The chapter ends with an observation that contemporary Pentecostalism seems to hold both the anti-intellectualist and the intellectualist attitudes. Chapter 7 focuses on the history of P.L. le Roux as a minister in the Dutch Reformed Church, his embracing of Zionism and his impact on the rise of AICs as well as his role as the second leader of AFM in South Africa. Another chapter on history is chapter 11 which traces the history of separation within the AFM on the basis of race. Lastly, chapter 12 discusses the contribution of John G. Lake to the AFM and the resultant African Independent Churches (AICs).

The theme of Pentecostal history and theology of healing receives a lot of attention in this book. I found these chapters very useful in teaching a course on History and Doctrine of Pentecostal Christianity. Chapter 6 gives a Pentecostal perspective on demonisation and deliverance. The chapter argues that demonisation is closely connected with illness and diseases and therefore should be well understood in the practice of Pentecostal healing. Other chapters discussing Pentecostal history and theology of healing are chapters 8,9 and 10. Chapter 8 traces the historical development of the teaching and practice of divine healing in the AFM from 1908 to contemporary times. The author discusses changing views, from the denial of 
modern medicine to its current incorporation in the church doctrine. Chapter 9 discusses the same doctrine of healing, but now addressing issues of non-healing in light of Jesus' teaching on the kingdom of God. Lastly, chapter 10 focuses on faith and prayer as important elements in the theology of healing. The chapter defines faith and prayer as it addresses questions on the role of the patient and healer in the Pentecostal doctrine of divine healing.

The last set of chapters I review in this book deals with Pentecostal hermeneutics. This is a topic that still requires a lot of attention and indeed this book provides a good starting point for its analysis. The way Pentecostals interpret biblical texts is quite different from how this is done in other churches, particularly the historical churches. Chapter 2 attempts a definition of Pentecostal hermeneutics. In short, the chapter shows the presence of the Holy Spirit in the hermeneutical process as differentiating Pentecostal hermeneutics from other hermeneutics. The last two chapters of the book then address how Pentecostals read specific books of the Bible. Chapter 13 looks at the reading of the Old Testament in general, while Chapter 14 looks at how Pentecostals infer the second coming of Jesus from Daniel 2.

This is indeed a very useful book in the area of Pentecostal studies. Although it focuses on the AFM in South Africa, its argument can be applied to Pentecostal Christianity as practised outside South Africa and the AFM. The book is based on rich primary data in the form of church minutes, which are usually difficult to access for an outside scholar. Nel, being a minister of the AFM, therefore provides rare insight, which brings to the public very valuable information. The author's training in New Testament Studies in particular, and Biblical Studies in general, comes in handy in the analysis of Pentecostal theology and can be easily noted. The book also provides a rich bibliography that can help the reader access more literature on the subject. Key resources on Pentecostal Christianity were utilised.

I only wish the author had put the various sections into some related structure with similar themes, as I have tried to do in my review of the book. Otherwise, many chapters read independently, as they are not connected together. As a result, one notices a repetition of a number of issues here and there. It is also surprising that the author did not address the Pentecostal doctrine of prosperity, which is currently 'trending', particularly in Southern African Christianity. I suspect that any reader who reads the title of the book will likely expect the book to address the doctrine of prosperity.

Be that as it may, this is a book anyone serious about knowledge of the mushrooming Pentecostal churches needs on their book shelf. 